\title{
ORGANIC AND MINERAL FERTILIZERS EFFECTS ON THE PERFORMANCE OF SWEET MAIZE (ZEA MAYS L. SACCHARATA STRUT.) IN SOUTH EASTERN RAINFOREST ZONE OF NIGERIA
}

\author{
UWAH D.F. ${ }^{* 1}$, ENEJI A.E. ${ }^{2}$, ESHIET U.J. ${ }^{1}$ \\ ${ }^{1}$ Department of Crop Science, University of Calabar, Calabar, Nigeria \\ 2Department of Soil Science, University of Calabar, Calabar, Nigeria \\ *Correspondence Author: E-mail: dfu55@yahoo.ca
}

Received: February 23, 2011; Accepted: March 31, 2011

\begin{abstract}
Growth and yield response of sweet maize (Zea mays $L$. saccharata Strut.) to rates of poultry manure (PM) and NPK 20-10-10 fertilizer was studied under field condition in 2010 late growing season in Calabar, a humid forest agro ecology of south eastern Nigeria. Treatments comprised of three rates of PM $(0,5$ and $10 t / h a)$, factorially combined with four rates of NPK $(0,200,400$ and $600 \mathrm{~kg} / \mathrm{ha})$ and arranged into a randomized complete block design with three replications. Application of PM at the highest rate significantly increased plant height, number of leaves/plant, number of cobs/plant, unhusked and dehusked green cob yields and also hastened days to $50 \%$ tasselling. The highest rates of PM and NPK maximized leaf area index (LAl), number of grains/cob and harvest index (HI) whereas total dry matter (TDM), weight of grains/cob, cob yield/ha and total grain yield peaked at $10 \mathrm{t} / \mathrm{ha}$ PM and $400 \mathrm{~kg} / \mathrm{ha}$ NPK fertilizer. The $10 \mathrm{t} / \mathrm{ha}$ PM rate and $400 \mathrm{~kg} / \mathrm{ha}$ NPK increased TDM by 43 and $91 \%$ and total grain yield by 101 and 34\% respectively, compared with the control. Poultry manure at 10t/ha in combination with $400 \mathrm{~kg} / \mathrm{ha}$ NPK fertilizer out-yielded other treatments in terms of biomass yield, cob yield/ha, harvest index and total grain yield.
\end{abstract}

Key words: Sweet maize, NPK 20-10-10 fertilizer, poultry manure, biomass yield, green cob yield, grain yield.

\section{INTRODUCTION}

Sweet maize (Zea mays L. saccharata Strut.) mostly grown in the United States, East Asia and some European countries, has become popular among the elites in African countries [1]. It is distinguished from other maize varieties by its delicious taste, high sugar content when in the milk or immature state and by its wrinkled, translucent kernels when dry. Sweet maize is usually eaten in the immature state as a fresh vegetable; boiled, steamed or roasted. When cut from the cob, it can be used in a wide variety of vegetable mixtures, soups or stew and for canning purposes. At optimum market maturity stage, sweet maize contains $5-6 \%$ sugar, $10-11 \%$ starch, $3 \%$ water soluble polysaccharides, $70 \%$ water, moderate amounts of protein, vitamins $A$ and $K$ [2].

Sweet maize is a fairly heavy feeder and soil fertility is critical for high yield [3] The low yield in other maize varieties grown in Nigeria has been partly attributed to depletion of organic matter and soil nutrients [4]. [5], observed that the top soils of south eastern Nigeria are predominantly very fragile and delicate and as a result suffer rapid decline in fertility after cultivation. Under the characteristically intense rainfall and rapid mineralization, the organic matter level falls drastically and consequently losses of some nutrients especially the cations through leaching occur and this lowers the soil pH. Inappropriate cultural practices such as continuous cropping on these fragile soils and bush burning exacerbated by the sandy nature of the soils further compound the problem [6]. A lot of efforts have been directed at finding solutions to low productivity of crops on Nigerian soils. The rising cost of inorganic fertilizers coupled with their inability to condition the soil and their polluting effect on the environment has directed attention to organic manures in recent times [6]; recommended the use of green manure as a supplement to inorganic fertilizer or as an alternative where inorganic fertilizers are not readily available. Poultry manure (PM) is an excellent organic fertilizer as it contains both macro and micro nutrients in available forms during mineralization. In contrast to organic fertilizer, it adds organic matter to soil which improves soil structure, soil aeration, nutrient retention, soil moisture holding capacity and water infiltration [7, 8]. Poultry manure has also been reported to supply $P$ more readily to plants than other organic manure sources [9]. Nutrients contained in organic manures are released more slowly and are stored for a longer period in the soil thereby ensuring a long residual effect [10]. The slow release of nutrients from organic manures can 
wisely be complemented by enriching them with inorganic nutrients that will be released faster and utilized by crops to compensate for the late start in nutrient release by organic manures [11]. The integration of organic and inorganic sources of nutrients not only supply essential nutrients but also have some positive interaction with inorganic fertilizers to increase their efficiency and thereby reduce environmental hazards [12, 11, 13].

Although studies have been conducted on the nutrition of some maize types in the rainforest agroecology of Nigeria, little is known about nutrient management for sweet maize production in the area. Since the recommendations for other maize types cannot be adopted for sweet maize and in view of the growing interest in sweet maize as a cash crop by peasant farmers in the zone, there is need for research-based data for guidance. Our objective was to evaluate the performance of sweet maize under the combined use of poultry manure and NPK fertilizer.

\section{MATERIALS AND METHODS}

A field experiment was carried out during the late planting season from August - November, 2010 in Calabar south eastern rainforest zone of Nigeria (40 $57^{\prime} \mathrm{N}, \quad 8019^{\prime} \mathrm{E} ; 37 \mathrm{~m}$, altitude). The zone is characterized by a bimodal annual rainfall distribution ranging from $3000-3500 \mathrm{~mm}$ with a long rainy season which starts in March while the short rainy season extends from September to November after a short dry spell of uncertain length in August. The dry season is usually from December to February. The mean annual temperature ranges from 27 to $35^{\circ} \mathrm{C}[14,15]$. The soil is acidic and is classified as Ultisols, characterized by low $\mathrm{pH}$, organic matter, and nutrient status, and usually deficient in multiple nutrients $[16,17]$. The experiment investigated the response of sweet maize (Zea mays L. saccharata Strut.) variety ND 4420, developed by the China Maize Centre, Beijing, to three rates of poultry manure (PM) $(0,5$ and $10 \mathrm{t} / \mathrm{ha})$ and four rates of NPK 20-10-10 fertilizer (F) (0, 200, 400 and $600 \mathrm{~kg} / \mathrm{ha})$. The treatment combinations were factorized and fitted into a randomized complete block design with three replications. Poultry manure was obtained from a deep litter system layer pens of the Teaching and Research Farm of the University of Calabar, with the birds fed with finisher diet. The bedding materials consisted mainly of wood shaving and saw dust. The NPK 20-10-10 fertilizer was sourced from a factory formulated type commonly used by the peasant farmers. Composite samples of the poultry manure were air dried, crushed, sieved and analyzed for chemical properties [18]. Soil samples were collected from the site at depths $0-30 \mathrm{~cm}$ prior to manure and fertilizer applications and analyzed for physico-chemical properties using procedures described in [18]. The relevant physical and chemical analyses of the soil and manure are summarized in Table 1. The site was cleared of vegetation with machete, ploughed to a depth of $20 \mathrm{~cm}$, and marked out into three blocks of 12 plots each. Each gross plot size was $1.5 \mathrm{~m} \times 3.0 \mathrm{~m}$ $\left(4.5 \mathrm{~m}^{2}\right)$, and the net plot size from which growth and yield attributes were measured was $1.0 \mathrm{~m} \times 1.8 \mathrm{~m}$ $\left(1.8 \mathrm{~m}^{2}\right)$. Plots were separated by a path of $1 \mathrm{~m}$ while blocks were kept at a distance of $1.5 \mathrm{~m}$ between them. Sowing was done on flat beds on 14th August, 2010. Three seeds were sown per stand at a spacing of $25 \times 60 \mathrm{~cm}$ and thinning of seedlings to one per stand was carried out two weeks after sowing (WAS) to give 30 plants per plot and 66,666 plants per hectare. The poultry manure was incorporated into the soil of the replicated plots in a single dose as per the various treatments and allowed to decompose for two weeks before planting while the NPK fertilizer was split applied twice. The first half at 2WAS, while the second half was side-dressed 5 WAS about $8 \mathrm{~cm}$ deep and $15 \mathrm{~cm}$ away from the plants. Manual weeding was done twice at 4 and 7WAS by hand pulling and hoeing. Harvesting was done in two stages - milk stage (green stage) and fully mature stage. Green harvesting was done 67 days after sowing from 6 randomly selected plants in the net plot area as indicated by the drying and browning of the silks, fullness of the tip kernels, and firmness of the unhusked ears. The fully mature cobs were harvested 82 days after sowing from the remaining 6 plants in the net plot area, and sun-dried to $14 \%$ moisture content. From these 12 plants, the following parameters were determined: plant height, number of leaves/plant, leaf area index, number of days to $50 \%$ tasselling, total dry matter/plant, number of cobs/plant, unhusked green cob weight, dehusked green cob weight, number of grains/cob, weight of grains/cob, cob yield/hectare, harvest index and total grain yield/hectare. Data were subjected to analysis of variance as described in [19] and the treatment means were compared using Fisher's Least Significant Difference (LSD) at the $5 \%$ level of probability [20].

\section{RESULTS}

Table 1 shows the physico-chemical properties of the experimental soil and the chemical composition of the poultry manure used in the study. The soil was loamy sand, low in nitrogen $(\mathrm{N})$, potassium $(\mathrm{K})$ and organic carbon, but high in phosphorus $(P)$ with a slightly acidic $\mathrm{pH}(6.70)$ reaction. The poultry manure used was generally high in all major nutrients as well as trace elements. Table 2 shows the effects of poultry manure and NPK fertilizer on plant height and leaf number per plant. Maximum plant height $(124 \mathrm{~cm})$ and number of leaves/plant (9.82) at 7WAS were obtained from plots amended with 10t/ha PM but the response to the NPK fertilizer rates was not significant across sampling 
periods. Leaf area index (LAl) at the two sampling periods, equally peaked at the highest PM rate (Table 3). There was significant effect of NPK on $\mathrm{LAl}$ with the $600 \mathrm{~kg} / \mathrm{ha}$ rate producing the highest LAl which was however, statistically similar to the $\mathrm{LAl}$ at $400 \mathrm{~kg} / \mathrm{ha}$ rate. Plants on plots with no poultry manure, tasselled later than those supplied either with 5 or 10t/ha PM while the effect of NPK on days to $50 \%$ tasselling was not significant (Table 3 ). The two fertilizers improved the total dry matter yield. There was no significant difference between the dry matter yield at 5 and 10t/ha rates of PM even though the 10t/ha rate produced a higher yield of $101.97 \mathrm{~g} /$ plant as against $85.44 \mathrm{~g} /$ plant. Plots that received $400 \mathrm{~kg} / \mathrm{ha}$ NPK treatment, significantly outyielded the other treatments in terms of dry matter production. Dry matter gains decreased drastically by $29.5 \%$ when the NPK rate was increased from 400 to $600 \mathrm{~kg} / \mathrm{ha}$. The interaction effect between PM and NPK, showed that the combination of 10t/ha PM with $400 \mathrm{~kg} / \mathrm{ha}$ NPK produced the heaviest total dry matter. This was heavier than the dry matter yield obtainable when either $10 \mathrm{t} / \mathrm{ha} P M$ or $400 \mathrm{~kg} / \mathrm{ha}$ NPK fertilizer was applied alone and more than twice the dry matter yield obtainable from the untreated control plots.

Poultry manure application significantly increased the number of cobs/plant, number of grains/cob, weight of grains/cob and cob yield/hectare especially at the application rate of 10t/ha (Table 4). The highest number of grains/cob was obtained at $600 \mathrm{~kg} / \mathrm{ha}$ NPK application while the $400 \mathrm{~kg} / \mathrm{ha}$ rate produced the heaviest grains/cob and cob yield/ha respectively. The interaction between PM and NPK showed that the number of grains/cob was highest with the combination of PM at $10 \mathrm{t} / \mathrm{ha}$ and $600 \mathrm{~kg} / \mathrm{ha}$ NPK fertilizer while the weight of grains/cob and cob yield/ha peaked with the combination of $10 \mathrm{t} / \mathrm{ha} \mathrm{PM}$ and $400 \mathrm{~kg} / \mathrm{ha}$ NPK fertilizer.

The data for grain yields and harvest index are presented in Table 5. The inorganic fertilizer rates had little effects on green cob yields. However, the 10t/ha PM rate significantly improved cob yield relative to other PM rates. Application of different rates of PM had significant effect on harvest index $(\mathrm{HI})$ as indicated in Table 5. Comparison of treatment means showed that the maximum $\mathrm{HI}$ $(35.75 \%)$ was recorded from maize crop manured at 10t/ha which however, was statistically at par with that of 5t/ha PM rate. The highest $\mathrm{HI}$ was also obtained at the highest NPK rate $(34.91 \%)$ even though this did not differ significantly from the $\mathrm{HI}$ recorded at $400 \mathrm{~kg} / \mathrm{ha}$ NPK $(33.26 \%)$. The PM $\mathrm{x}$ NPK interaction on $\mathrm{HI}$ was significant with the combination of $10 \mathrm{t} / \mathrm{ha} \mathrm{PM}$ and $400 \mathrm{~kg} / \mathrm{ha}$ NPK producing the highest $\mathrm{HI}$. The total grain yield also followed the same trend as those of the dry matter and cob yields/ha. The 5 and 10t/ha PM improved yield by 42 and $101 \%$ respectively, over the control plots. Each increment in NPK rates significantly increased grain yield up to the $400 \mathrm{~kg} / \mathrm{ha}$ rate but yield was reduce by $14 \%$ at the $600 \mathrm{~kg} / \mathrm{ha}$ NPK rate. The PM x NPK interaction effect was significant with the combination of $10 \mathrm{t} / \mathrm{ha} P M$ and $400 \mathrm{~kg} / \mathrm{ha}$ NPK giving the best yield (2.94t/ha). This combination resulted in a 25 and $48 \%$ more grain yield than obtainable when either $10 \mathrm{t} / \mathrm{ha}$ PM or $400 \mathrm{~kg} / \mathrm{ha}$ NPK was applied alone and more than twice the yield obtainable from the untreated control plots.

\section{DISCUSSION}

The overall results indicated that tallest plants with highest leaf number and LAl occurred at the highest rates of poultry manure and NPK fertilizer application. The greater plant height, number of leaves and LAl values recorded from the organic fertilizer throughout the sampling periods, relative to inorganic fertilizer application is attributable to availability of balanced nutrients in the PM. Superior growth and LAl under combined high rates of organic and inorganic fertilizers have been reported by other workers [21, 22, 23]. The earliness in tasselling following PM application, could be attributed to the relatively higher inherent nutrients in the PM which promoted vigorous foliage growth, increased meristermatic and more intense physiological activities in the plants which favoured the synthesis of more photoassimilates and early flowering. These results are consistent with those of $[23,24]$ who observed a reduction in member of days to $50 \%$ tasselling in maize with increases in rates of fertilizers used. However, [11] observed that more availability of $\mathrm{N}$ and $\mathrm{P}$ under high fertilization delayed the tasselling period.

Total dry matter yield was maximized at the highest PM rate, while this parameter peaked at the $400 \mathrm{~kg} / \mathrm{ha}$ rate of NPK fertilizer (Table 3). High correlation between photosynthetic rate and LAl or dry matter production was observed by [23] with the lowest LAl and dry matter of sweet corn measured in control plots [25] observed that $\mathrm{N}$ deficiency decreased maize LAl, resulting in shorter plants with less dry matter accumulation. Application of 5 and 10t/ha of PM increased total dry matter yield by 20 and $43 \%$, whereas the 200,400 and $600 \mathrm{~kg} / \mathrm{ha}$ NPK rates gave corresponding increases of 25.6, 91.0 and $47.6 \%$ respectively. Poultry manure in combination with NPK produced the highest total dry matter yield (124.12 g/plant) possibly due to synergy. The $5 \mathrm{t} / \mathrm{ha}$ PM plus $400 \mathrm{~kg} / \mathrm{ha} \mathrm{NPK}$ produced higher dry matter gains than the full dose of PM and NPK alone. This implies that integrated application of organic and inorganic fertilizer might be more desirable than either type of fertilizer alone. [26] reported that PM plus one-half the recommended inorganic fertilizer rate, yielded much greater amount of green fodder of corn than the full rate of NPK alone. The number of cobs/plant was directly related to the amount of amendment applied as reported previously $[27,28]$. The reason may be 
adequate and balanced supply of plant nutrients by the poultry manure throughout the growth period. The increases in yield attributes under combined PM and NPK used were mainly due to availability of more nutrients from the two fertilizers for plant development up to cob formation. These results are similar to the findings of [29], who reported that precise application of manure and mineral fertilizer to maize can be as affective as commercial $\mathrm{N}$ fertilizer for yield response [30] and [28] reported that available $N$ and $P$ in soil increased with increase in organic matter [31]; recommended the combined application of PM and NPK because of the complementary and synergistic effects of the fertilizers on maize growth and yield.

Grain yield in terms of unhusked green cob and dehusked green cob yields were significantly affected only by the application of PM with the highest yields obtained at the 10t/ha rate. Different levels of the fertilizers had significant effect on harvest index. The higher the $\mathrm{HI}$, the greater was the grain yield. The combined effect of PM at $10 \mathrm{t} / \mathrm{ha}$ and NPK at $400 \mathrm{~kg} / \mathrm{ha}$ produced superior $\mathrm{HI}$ compared with those obtained at either poultry manure or NPK fertilizer alone at any level of application. This resulted is $25 \%$ more $\mathrm{HI}$ than $400 \mathrm{~kg} \mathrm{NPK}$ and $15.6 \%$ more $\mathrm{HI}$ than the single application of 10t/ha PM; and more than twice the $\mathrm{HI}$ obtained at the control plots. Grain yield followed similar trend as that of LAl, dry matter yield, cob yield/ha and harvest index. Application of 200, 400 and $600 \mathrm{~kg} / \mathrm{ha}$ NPK fertilizer increased grain yield by $11.4,33.5$ and $17.5 \%$ respectively when compared with the control. Higher application of $600 \mathrm{~kg} / \mathrm{ha}$ increased maize yield at a reduced rate, a possible case of diminishing returns. The combined application of PM and NPK maximized grain yield possibly due to more grains/cob, number of cobs/plant and better grain development. Plant nutrient use efficiency increased with combined organic and inorganic nutrient application [32, 27, $33,34]$ reported higher yields in maize from a combined use of NPK fertilizer and PM than from sole applications. Maize grown with complementary fertilizers and those with sole inorganic fertilizer treatment were comparable because nutrient released early from the inorganic fertilizer was utilized for optimum growth. Combining 10t/ha PM with a lower rate of NPK $(400 \mathrm{~kg} / \mathrm{ha})$ may reduce inorganic fertilizer application thereby precluding excessive salt concentrations in the soil solution and most probably reduce costs.

\section{CONCLUSION}

The study showed that poultry manure application at 10t/ha would increase yields of sweet maize by more than 100 per cent. Use of high tonnage of organic manures to achieve high yields in sweet maize could be reduced by supplementing the manure with inorganic fertilizers. For the area under study, the 10t/ha PM $+400 \mathrm{~kg} / \mathrm{ha}$ NPK fertilizer is recommended because of its superior synergistic effects on the performance of sweet maize.

\section{REFERENCES}

[1] Badu-Apraku B. and Fakorede M.A.B. (2006) (Zea mays L.) Wageningen, Netherlands Backhuys Publishers, Leiden, Netherlands/CTA, Wageningen, Netherlands 229-237.

[2] Oktem A. G. and Oktem A. (2005) Asian J. Plant Sci. 4:361-364.

[3] Fernandez Santos F. X., Zekri S. and Herruzo Casimiro A. (1992) Invest. Agr. Econ. 7:325-338.

[4] Lal R. and. Greenland D. J (1979) R. Laland D. J. Greenland. (eds). J. Wiley and Sons New York.

[5] Obi M. E. and Ebo P.O. (1994) Bioresource Technology 51(2-3):117-123.

[6] Shehu Y.W.S., Alhassan W.K., Aliyu M.A. and Philips C. J. C. (1997) Tropical Greenland, 32:139-142.

[7] Akinrinde E.A., Olubakin D.A., Omoloso S.O. and Ahmed A.A. (2006) Agric. J. 1(2):96-103.

[8] Deksissa T., Short I. and Allen J. (2008) In: Proceeding of the UCOWR/NIWA Annual Conf: Int'l Water Resources Education; July 22-24, 2008, Durham, NC.

[9] Garg S. and Bahla G. S. (2008) Bioresource Technology, 99(13):57735777.

[10] Sharma A. R. and Mittra B.N. (1991) J. Agric. Sci., (Camb). 117:313-318.

[11] Khaliq T., Mahmmod T., Kamel J. and Masood A. (2004) Int'l. J. Agric. Biol. 6(2):260-263.

[12] Ahmad N., Rashid M. and Vaes A. G. (1996) NFDC pp142-149.

[13] Uwah D.F., Udoh A.U. and Iwo G. A. (2011) Int'l. J. Agric. Scis., 3(1):1-6.

[14] Harold A. A. (1970) Collage Atlas. MacMillan Publishers Ltd., Lagos, Nigeria.

[15] Cross River Basin and Rural Development Authority (1995) Cross River Basin News. A Biennial News Letter, 1(7), 52.

[16] Sanchez P.A., Stoner E.R. and Pushparajah E.D. (1987) Proc. IBSRAM Inaugural Workshop. Bangkok, Thailand, 107.

[17] Brady N.C. and Weil R.R. (1996) Prentice-Hall Inc. New Jersey, USA, 740.

[18] IITA (1982) Selected methods of soil and plant analysis. International Institute of Tropical Agriculture Manual Series No. 7 Ibadan, Nigeria. 
[19] Snedecor C.W. and Cochran W.G. (1967) Statistical methods, lowa State Uni. Press, USA, 507.

[20] Gomez K. A. and Gomez A. A. (1984) Statistical Procedures for Agricultural Research (2nd ed.) John Wiley and Sons, New York 680.

[21] Mitchell C.C. and Tu S. (2005) Agron. J. 97:399-407.

[22] Ayoola O.T. and Makinde E. A. (2009) African J. Food, Agric. Nutrition and Dev. 9(1):580-592.

[23] Efthimiadou A., Bilalis D., Karkanis A., Froud-Williams H. B. and Eleftherochor nos (2009) Bot. Hort. Agrobot. Cluj 37(2):104-111.

[24] Orosz F., Jakab S., Losak T. and Slezak K. (2009) J. Environmental Bio. 30(6):933938.

[25] Zhao D., Reddy R.K., Kakani V.G., Reddy V.R. and Carter G.A. (2003) Plant and soil. 257:205-217.
[26] Vasanthi D. and Kumaraswamy K. (2000) J. Indian Soc. Sci., 48(3):510-515.

[27] Tamayo V. A., Munoz A.R. and Diaz A.C. (1997) Actualidades corpoica, 108:19-24 (Field Crop Abst; 15:3970; 1998).

[28] Shah K.P. and Arif M. (2000) Sarhad J. Agric; 16:461-5.

[29] Zhang H.S., Meal D. and Tomko J. (1998) J. Plant Nut. 21:287-296.

[30] Sharma M.P. and Gupta J. P. (1998) Indian J. Agric. Sci., 68:715-7.

[31] Boateng S.A., Zickermann J. and Kornaharens M. (2006) West Africa J. App. Eco., 9:1-11.

[32] Das M., Singh B.P., Ram M. and Parsad R.N. (1992) J. Indian Soc. Soil Sci., 40:580-3.

[33] Makinde E. A., Agboola A. A. and Oluwatoyinbo F. I. (2001) Moor J. Agric. Res. 2:15-20.

[34] Adeniyen O.N. and Ojeniyi S.O. (2005) Nig. J. Soil. Sci., 15:34-41. 
Table 1-Physico-chemical properties of the top soil $(0-30 \mathrm{~cm})$ of the experimental field at Calabar, Nigeria and chemical properties of poultry manure used

\begin{tabular}{|c|c|c|c|}
\hline \multicolumn{2}{|c|}{ Composition Soil } & \multicolumn{2}{|c|}{ Poultry manure } \\
\hline \multicolumn{2}{|c|}{ Physical composition (g/kg) } & & \\
\hline$\overline{\text { Sand }}$ & 778.6 & $\mathrm{~N}(\%)$ & 2.31 \\
\hline Silt & 132.8 & $\mathrm{P}(\mathrm{mg} / \mathrm{kg})$ & 2989.2 \\
\hline Clay & 88.6 & $\mathrm{~K}(\mathrm{mg} / \mathrm{l})$ & 7032.0 \\
\hline Textural class & Loamy sand & $\mathrm{Mg}(\mathrm{mg} / \mathrm{l})$ & 148.1 \\
\hline \multicolumn{2}{|c|}{ Chemical characteristics } & $\mathrm{Ca}(\mathrm{mg} / \mathrm{l})$ & 206.5 \\
\hline $\mathrm{pH}\left(\mathrm{H}_{2} \mathrm{O}\right)(1: 2.5)$ & 6.70 & $\mathrm{Na}(\mathrm{mg} / \mathrm{l})$ & 448.1 \\
\hline Organic Carbon $(\mathrm{g} / \mathrm{kg})$ & 7.10 & $\mathrm{Mn}(\mathrm{mg} / \mathrm{l})$ & 107.6 \\
\hline Available P (mg/kg) & 19.66 & $\mathrm{Cu}(\mathrm{mg} / \mathrm{l})$ & 4074.0 \\
\hline Total N (g/kg) & 0.40 & $\mathrm{Fe}(\mathrm{mg} / \mathrm{l})$ & 347.0 \\
\hline \multicolumn{2}{|c|}{ Exchangeable bases (cmol/kg) } & $\mathrm{Zn}(\mathrm{mg} / \mathrm{l})$ & 120.9 \\
\hline $\mathrm{Ca}$ & 2.40 & & \\
\hline $\mathrm{Mg}$ & 1.10 & & \\
\hline $\mathrm{K}$ & 0.08 & & \\
\hline $\mathrm{Na}$ & 0.05 & & \\
\hline EA & 2.10 & & \\
\hline ECEC & 5.73 & & \\
\hline $\mathrm{BS}(\%)$ & 63.35 & & \\
\hline
\end{tabular}

Table 2- Maize height (cm) and number of leaves as affected by poultry manure and NPK 20-10-10 fertilizer in Calabar, Nigeria

\begin{tabular}{|c|c|c|c|c|c|c|c|c|}
\hline \multirow{2}{*}{ Treatment } & \multicolumn{4}{|c|}{ Poultry manure (t/ha) } & \multicolumn{4}{|c|}{ Poultry manure (t/ha) } \\
\hline & 0 & 5 & 10 & Mean & 0 & 5 & 10 & Mean \\
\hline $\begin{array}{c}\text { NPK 20:10:10 } \\
\text { (kg/ha) }\end{array}$ & \multicolumn{4}{|c|}{$\begin{array}{l}\text { Plant height }(\mathrm{cm}) \\
\text { 5WAS }\end{array}$} & \multicolumn{4}{|c|}{$\begin{array}{l}\text { Number of leaves/plant } \\
\text { 5WAS }\end{array}$} \\
\hline 0 & 24.00 & 31.00 & 35.50 & 30.17 & 7.33 & 8.50 & 9.33 & 8.39 \\
\hline 200 & 28.50 & 36.83 & 50.83 & 38.72 & 7.83 & 8.83 & 10.00 & 8.89 \\
\hline 400 & 32.33 & 45.83 & 52.17 & 43.44 & 8.33 & 8.83 & 10.00 & 9.05 \\
\hline 600 & 35.33 & 35.17 & 49.67 & 40.06 & 8.67 & 9.83 & 9.83 & 9.44 \\
\hline Mean & 30.04 & 37.21 & 47.04 & & 8.04 & 9.00 & 9.79 & \\
\hline $\begin{array}{c}\text { NPK 20:10:10 } \\
\text { (kg/ha) }\end{array}$ & \multicolumn{4}{|c|}{ 7WAS } & & & & \\
\hline 0 & 79.27 & 105.00 & 114.50 & 99.59 & 8.50 & 9.00 & 9.33 & 8.94 \\
\hline 200 & 99.00 & 108.33 & 123.83 & 110.39 & 8.83 & 9.33 & 9.63 & 9.26 \\
\hline 400 & 101.50 & 110.50 & 121.67 & 111.22 & 8.83 & 9.50 & 10.00 & 9.44 \\
\hline 600 & 103.17 & 90.27 & 136.00 & 109.81 & 9.00 & 9.17 & 10.33 & 9.50 \\
\hline Mean & 95.74 & 103.53 & 124.00 & & 8.79 & 9.25 & 9.82 & \\
\hline
\end{tabular}

LSD (0.05) between treatment means

Poultry manure (PM) NPK 20:10:10 (F)

$\mathrm{PM} \times \mathrm{F}$

Poultry manure (PM) NPK 20:10:10 (F)

$\mathrm{PM} \times \mathrm{F}$

\section{Plant height (cm) 5 WAS \\ 8.405 \\ NS \\ NS}

Plant height 7WAS

11.454

NS

NS

\section{Number of leaves/plant 5 WAS \\ 0.645 \\ NS \\ NS}

Number of leaves/plant 7WAS
0.515
NS
NS


Table 3- Leaf area index (LAl), days to 50\% tasselling and total dry matter (g/plant) of sweet maize as affected by poultry manure and NPK 20:10:10 fertilizer in Calabar, Nigeria

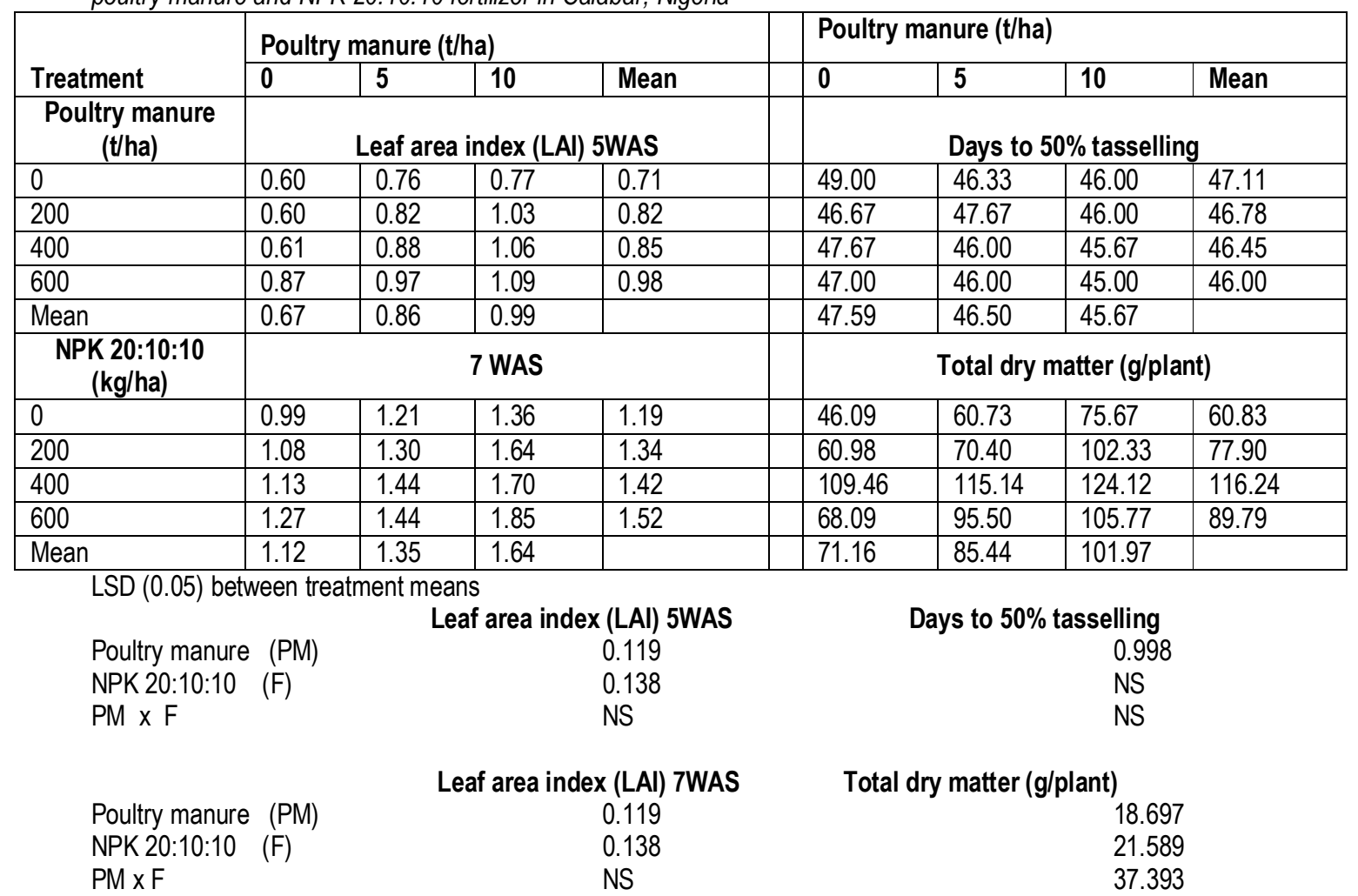

Table 4- Number of cobs/plant, number of grains/cob, weight of grains/cob, cob yield/hectare as affected by poultry manure and NPK 20-10-10 fertilizer in Calabar, Nigeria

\begin{tabular}{|c|c|c|c|c|c|c|c|c|}
\hline \multirow{3}{*}{$\begin{array}{c}\text { Treatment } \\
\text { NPK 20:10:10 } \\
\text { (kg/ha) }\end{array}$} & \multicolumn{4}{|c|}{ Poultry Manure (t/ha) } & \multicolumn{4}{|c|}{ Poultry Manure (t/ha) } \\
\hline & 0 & 5 & 10 & Mean & 0 & 5 & 10 & Mean \\
\hline & \multicolumn{4}{|c|}{ No. of cobs/plant } & \multicolumn{4}{|c|}{ Number of grains/cob } \\
\hline 0 & 1.00 & 1.00 & 1.17 & 1.06 & 127.00 & 196.00 & 243.00 & 185.56 \\
\hline 200 & 1.00 & 1.00 & 1.25 & 1.08 & 148.67 & 186.67 & 276.00 & 206.89 \\
\hline 400 & 1.00 & 1.25 & 1.33 & 1.19 & 149.00 & 214.00 & 284.67 & 215.89 \\
\hline 600 & 1.25 & 1.13 & 1.33 & 1.24 & 156.67 & 227.33 & 365.00 & 249.67 \\
\hline Mean & 1.06 & 1.10 & 1.27 & & 145.33 & 206.00 & 292.17 & \\
\hline $\begin{array}{c}\text { NPK 20:10:10 } \\
\text { (kg/ha) }\end{array}$ & \multicolumn{4}{|c|}{ Weight of grains/cob } & \multicolumn{4}{|c|}{ Cob yield/ha (t/ha) } \\
\hline 0 & 15.32 & 23.65 & 29.32 & 22.39 & 2.54 & 3.26 & 4.55 & 3.45 \\
\hline 200 & 17.94 & 22.52 & 33.30 & 24.96 & 3.41 & 4.02 & 5.09 & 4.17 \\
\hline 400 & 17.98 & 25.82 & 44.04 & 29.81 & 3.79 & 4.47 & 6.09 & 4.87 \\
\hline 600 & 18.90 & 27.43 & 34.35 & 26.36 & 3.80 & 4.72 & 5.36 & 4.54 \\
\hline Mean & 17.54 & 24.86 & 35.25 & & 3.39 & 4.12 & 5.27 & \\
\hline
\end{tabular}

LSD $(0.05)$ between treatment means

Poultry manure (PM) NPK 20:10:10 (F)

$\mathrm{PM} \times \mathrm{F}$

Poultry manure $(\mathrm{PM})$ NPK 20:10:10 (F)

$\mathrm{PM} \times \mathrm{F}$

No. of cobs/plant
0.169
NS
NS
Weight of grains/cob
2.629
3.036
5.258

No. of grains/cob 10.505

25.158

43.575

Cob yield/ha (t/ha)

0.196

0.196

0.339 
Table 5- Unhusked green cob weight ( $\mathrm{kg})$, dehusked green cob weight $(\mathrm{kg})$, harvest index (\%) and total grain yield (t/ha) as affected by poultry manure and NPK 20-10-10 fertilizer in Calabar, Nigeria

\begin{tabular}{|c|c|c|c|c|c|c|c|c|}
\hline \multirow{3}{*}{$\begin{array}{c}\text { Treatment } \\
\begin{array}{c}\text { NPK 20:10:10 } \\
\text { (kg/ha) }\end{array}\end{array}$} & \multicolumn{4}{|c|}{ Poultry Manure (t/ha) } & \multicolumn{4}{|c|}{ Poultry Manure (t/ha) } \\
\hline & 0 & 5 & 10 & Mean & 0 & 5 & 10 & Mean \\
\hline & \multicolumn{4}{|c|}{ Unhusked green cob weight (kg) } & \multicolumn{4}{|c|}{ Dehusked green cob weight (kg } \\
\hline 0 & 0.17 & 0.17 & 0.22 & 0.19 & 0.12 & 0.13 & 0.18 & 0.14 \\
\hline 200 & 0.17 & 0.17 & 0.27 & 0.20 & 0.12 & 0.13 & 0.21 & 0.15 \\
\hline 400 & 0.19 & 0.25 & 0.27 & 0.24 & 0.14 & 0.20 & 0.22 & 0.19 \\
\hline 600 & 0.18 & 0.19 & 0.29 & 0.21 & 0.13 & 0.15 & 0.24 & 0.17 \\
\hline Mean & 0.18 & 0.20 & 0.26 & & 0.13 & 0.15 & 0.21 & \\
\hline $\begin{array}{l}\text { NPK 20:10:10 } \\
\text { (kg/ha) }\end{array}$ & \multicolumn{4}{|c|}{ Harvest Index (\%) } & \multicolumn{4}{|c|}{ Total grain yield ( $\mathrm{t} / \mathrm{ha}$ ) } \\
\hline 0 & 16.47 & 27.75 & 32.37 & 25.53 & 1.02 & 1.50 & 1.95 & 1.49 \\
\hline 200 & 24.63 & 32.63 & 33.65 & 30.30 & 1.20 & 1.58 & 2.22 & 1.66 \\
\hline 400 & 27.07 & 33.62 & 39.10 & 33.26 & 1.20 & 1.83 & 2.94 & 1.99 \\
\hline 600 & 29.55 & 37.30 & 37.89 & 34.19 & 1.26 & 1.72 & 2.28 & 1.75 \\
\hline Mean & 24.43 & 32.83 & 35.75 & & 1.17 & 1.66 & 2.35 & \\
\hline
\end{tabular}

LSD (0.05) between treatment means

Unhusked green cob weight

(kg)

Poultry manure (PM)

NPK 20:10:10 (F)

PM $\times$ F

Poultry manure (PM) NPK 20:10:10 (F)

$\mathrm{PM} \times \mathrm{F}$
0.046

NS

NS

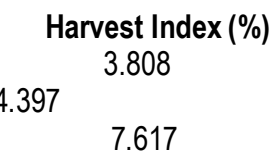

Dehusked green cob weight

$(\mathrm{kg})$

0.046

NS

NS

Total grain yield (t/ha)

0.196

0.196

0.339 